\title{
Multi-axial Analyses of Welding Stresses in High-Strength Steel Welds
}

\author{
Dirk Schroepfer ${ }^{1, a^{*}}$, Kerstin Flohr ${ }^{1, b}$, Arne Kromm ${ }^{1, c}$ and \\ Thomas Kannengiesser ${ }^{1, d}$ \\ ${ }^{1}$ Bundesanstalt für Materialforschung und -prüfung (BAM), 9.4 Division - Weld Mechanics, Unter den \\ Eichen 87, 12205 Berlin, GERMANY

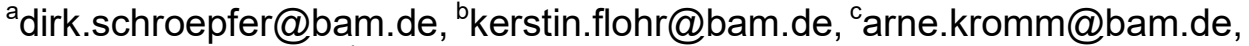 \\ dhomas.kannengiesser@bam.de
}

\section{Keywords: High-Strength Steel, Welding, Reaction Stress, X-Ray Diffraction}

\begin{abstract}
Today's efforts for lightweight design result in a growing application of high-strength structural steels from $960 \mathrm{MPa}$. In welded structures of these steels increased demands regarding component safety and a high elastic ratio should be considered. Hence, the prevention of an evolution of high weld-induced tensile residual stresses is required. Recent studies showed that component related restraint conditions of welds are able to elevate welding induced stresses to critical values, depending on material characteristics, the welding process and parameters. This work involves multi-axial welding loads as a consequence of the superposition of local residual stresses, global reaction stresses and moments, varying the welding parameters under different restraint conditions. The global welding loads are measured via GMA-weld tests in a special testing facility and via a DIC(Digital Image Correlation)-system in a slot weld. Local transverse residual stresses were analysed by means of X-ray diffraction. The application of a less amount of weld runs due to a modified welding parameters and welds seam configurations revealed as a beneficial approach to reduce welding loads in high-strength steels.
\end{abstract}

\section{Introduction}

In modern steel constructions, e.g. mobile cranes, high-strength steels are required to ensure low selfweights. Besides higher ratios of lifting capacity to total weight of such constructions, higher energy and cost efficiencies are provided [1]. A series of high-strength base materials and filler metals was developed by the steel producers, recently. S960QL is one of the most important steel grades for the mobile crane industry. However, the design of welded structures and the welding process become more challenging with increasing material strength due to higher requirements for the component safety, higher elastic ratios and closer technological boundaries [2], for instance the cooling time from $800{ }^{\circ} \mathrm{C}$ to $500{ }^{\circ} \mathrm{C}\left(\Delta t_{8 / 5}\right.$-cooling time). Besides ensuring metallurgical requirements by keeping a defined working range of heat control, high tensile residual stresses should be avoided. These stresses are contributors for crack initiation and may be detrimental for the lifetime, load capacity and component safety [3].

Several recent numerical and experimental studies revealed that loads and stresses due to welding are affected by an interaction of the welding parameters, the applied materials and the restraint, which is subjected to the design of the weld [4-8]. Regarding the influence of a hindered shrinkage of a weldment, the residual stress $\left(\sigma^{\mathrm{rs}}\right)$ formation should be differentiated into a local and a global scope. Following Fig. 1a, local restraint stresses $\sigma_{\text {loc }}$ develop due to inhomogeneous volume changes in the weld and HAZ. They are subjected to the material behaviour and welding process. If the weld is externally restrained, these local stresses are superimposed globally by normal reaction stresses $\sigma_{\mathrm{y}}$ due to the hindered lateral shrinkage $\Delta l$ of the component; see Fig. $1 \mathrm{~b}$. As a rule, component related restraints are accompanied by a restrained angular distortion $\Delta \beta$, which causes bending moments $M_{\mathrm{x}}$ while welding and cooling. Considering a multiaxial load analysis of welded components, the resulting bending stress $\sigma_{M x}$ should be additionally superimposed; see Fig. 1c. Existing analyses involved the interaction between heat control and stress buildup in welds under global restraint. Lower working temperatures (preheat and interpass temperature $T_{\mathrm{p} / \mathrm{i}}$ ) and

(c) (1) Content from this work may be used under the terms of the Creative Commons Attribution 3.0 license. Any further distribution of this work must maintain attribution to the author(s) and the title of the work, journal citation and DOI. Published under license by Materials Research Forum LLC. 
heat inputs significantly decrease the resulting reaction forces [4]. The modification of process parameters at modern power sources enables the weldability of narrow weld seams considering the seam configuration [9].
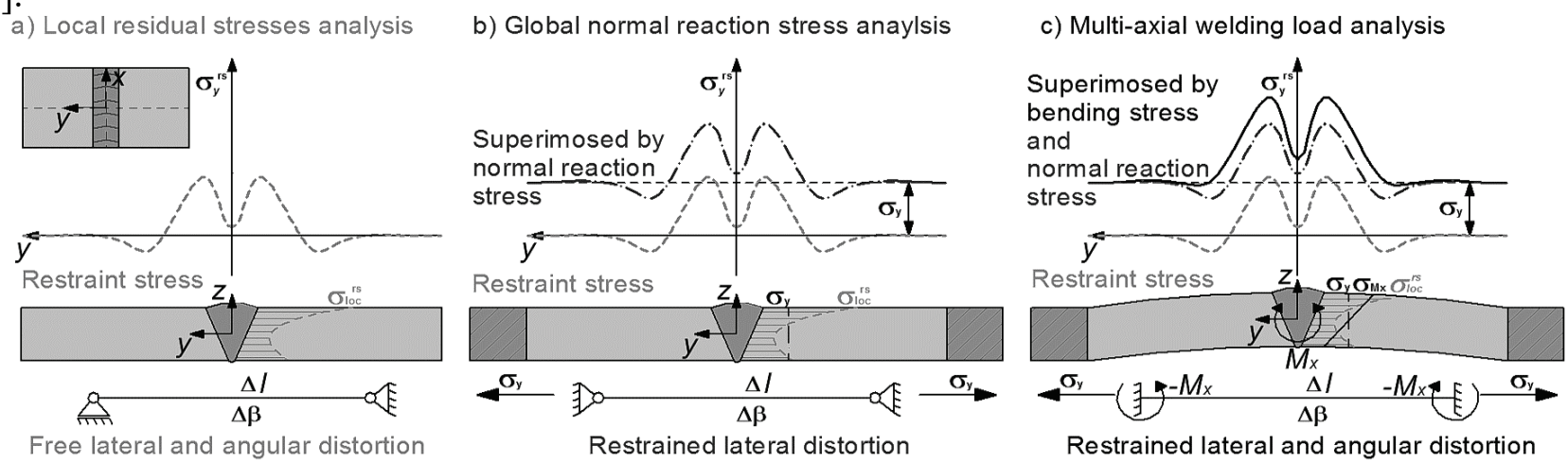

Fig. 1. Welding load and stress analyses considering restraints according to [4].

A reduced overall heat input and amount of filler metal for the same weld is possible, which may provide beneficial effects regarding distortion and residual stresses. However, an advanced understanding for stress prediction and optimization in high-strength steel component welds considering multiaxial loads is missing. Hence, this research focusses on the influence of the weld seam configuration and welding process parameters on the global reaction forces and bending moments in welded components.

\section{Experimental}

Test Material. Plates with a thickness of $20 \mathrm{~mm}$ of high-strength quenched and tempered fine grained structural steel S960QL were welded with a similar high-strength solid wire according to ISO 16834-A [10]. The chemical composition and mechanical properties are given in Table 1.

Table 1. Chemical compositions (FES, Fe balanced) and mechanical properties of the test materials.

\begin{tabular}{llllllllll}
\hline Element in \% & $\mathrm{C}$ & $\mathrm{Si}$ & $\mathrm{Mn}$ & $\mathrm{Cr}$ & $\mathrm{Mo}$ & $\mathrm{Ni}$ & $\mathrm{V}$ & $\mathrm{Nb}$ & $\mathrm{Ti}$ \\
\hline Base material (S960QL, EN 10025-6 [11]) & 0.16 & 0.32 & 1.24 & 0.20 & 0.61 & 0.05 & 0.040 & 0.015 & 0.003 \\
Filler material (G 89 6 M21 Mn4Ni2CrMo [10]) & 0.08 & 0.87 & 1.84 & 0.35 & 0.57 & 2.23 & 0.005 & - & 0.070 \\
\hline Property & $R_{\mathrm{p} 0.2}$ in MPa & $R_{\mathrm{m}}$ in MPa & $A_{5}$ in $\%$ & $A v$ in J at $-40{ }^{\circ} \mathrm{C}$ & $\mathrm{HV} 10$ \\
\hline Base material (mechanical testing) & 1035 & 1050 & 17 & 96 & & $332 \pm 8$ \\
Filler material (producer testing report) & 938 & 980 & 15 & 62 & & $354 \pm 7$ \\
\hline
\end{tabular}

Table 2. Welding parameters and variation of seam configuration and restraint condition.

\begin{tabular}{|c|c|c|c|c|c|c|c|c|c|c|}
\hline $\begin{array}{c}\text { Weld } \\
\text { preparation }\end{array}$ & $\begin{array}{l}\text { Welc } \\
\text { curren }\end{array}$ & & $\begin{array}{c}\text { Welding } \\
\text { voltage [V] }\end{array}$ & $\begin{array}{l}\text { Welding speed } \\
{[\mathrm{mm} / \mathrm{min}]}\end{array}$ & $\begin{array}{r}\text { Wire fe } \\
\text { speed }[\mathrm{m} / 1\end{array}$ & & $\begin{array}{l}\text { Welding } \\
\text { parameters }\end{array}$ & $\begin{array}{r}\text { Wor } \\
\text { peratu }\end{array}$ & $\begin{array}{l}\text { gi tem- } \\
T_{\mathrm{p} / \mathrm{i}}\left[{ }^{\circ} \mathrm{C}\right]\end{array}$ & $\begin{array}{c}\text { Heat input } \\
{[\mathrm{kJ} / \mathrm{mm}]}\end{array}$ \\
\hline V groove, $45^{\circ}$ & $265=$ & & $26.5 \pm 0.1$ & 330 & 8.7 & & Conv. & \multirow{2}{*}{\multicolumn{2}{|c|}{100}} & \multirow{2}{*}{1.3} \\
\hline $\mathrm{V}$ groove, $30^{\circ}$ & $320=$ & & $28.7 \pm 0.1$ & 400 to 420 & 11 & & Mod. & & & \\
\hline \multicolumn{5}{|c|}{ Test no. } & 1 & 2 & 3 & 4 & 5 & 6 \\
\hline Groove an & & $\alpha$ & & {$\left[{ }^{\circ}\right]$} & 45 & 30 & 45 & 30 & 45 & 30 \\
\hline \multicolumn{2}{|c|}{$\begin{array}{l}\text { Welding parameters } \\
\text { Restraint intensity }\end{array}$} & $\begin{array}{c}- \\
R_{\mathrm{F}}\end{array}$ & & $\begin{array}{l}- \\
/(\mathrm{mm} \cdot \mathrm{mm})]\end{array}$ & $\begin{array}{c}\text { Conv. } \\
0^{\mathrm{a}}\end{array}$ & $\begin{array}{r}\mathrm{Moc} \\
0^{\mathrm{a}}\end{array}$ & $\begin{array}{l}\text { Conv. } \\
3^{b}\end{array}$ & $\begin{array}{l}\text { Mod. } \\
3^{\mathrm{b}}\end{array}$ & $\begin{array}{l}\text { Conv. } \\
10^{\mathrm{c}}\end{array}$ & $\begin{array}{l}\text { Mod. } \\
10^{\circ}\end{array}$ \\
\hline
\end{tabular}

Welding parameters of the power source: Conv.: transitional arc, Mod.: modified spray arc;

${ }^{a}$ Free shrinking weld test, ${ }^{b}$ Restrained weld test in the 2-MN-testing facility, ${ }^{\mathrm{c}}$ Self restrained weld test (slot weld).

Welding Parameters. All welds were performed with automated GMA multilayer welding. The welding parameters are shown in Table 2. The welding parameters and seam preparation by means of groove angle were varied. The $45^{\circ} \mathrm{V}$-butt joints were welded with the conventional and the $30^{\circ}$ groove angles with the modified welding parameters. Considering technological and mechanical requirements of the welds, cooling times were measured for the applied heat control ( $\Delta t_{8 / 5}=6 \mathrm{~s}$ to $\left.8 \mathrm{~s}\right) . \Delta t_{8 / 5}$-times and tested properties of the welds are according to the specifications.

Weld Tests and Dimensions. For a variation of the restraint conditions, free shrinking, externally restrained and self-restrained weld tests were performed; see Fig. 2 for dimensions and build-up sequence. The external restraint in weld tests no. 3 and 4 was conducted using a special in-house developed 2-MN- 
testing facility $[4,7]$. In this test setup, a shrinkage restraint and synchronous measurement of forces and stresses of the weld were achieved; see Fig. $2 \mathrm{~b}$ and $3 \mathrm{~b}$.

Fig. 2. Specimen dimensions for the

free shrinking (a), externally

restrained at 2-MN-testing facility setup (b) and self-restrained weld tests (c); d) build-up sequences for groove angles $45^{\circ}$ and $30^{\circ}$

(1 - specimen / themocouples; 2 - test desks / hydraulic clamping (500 bar); 3 -hydraulic cylinder (200 bar); $\quad 4$ - piston rod, 5 load cell; 6 - weld seam, start and end tabs; 7 - DIC area).

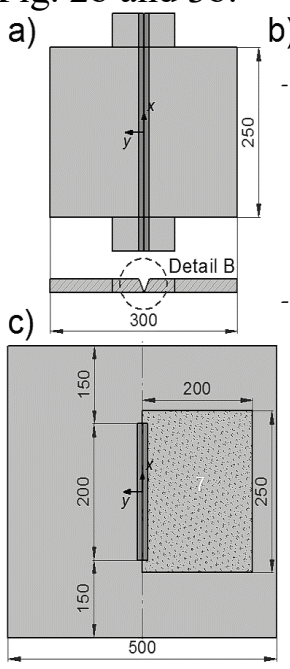

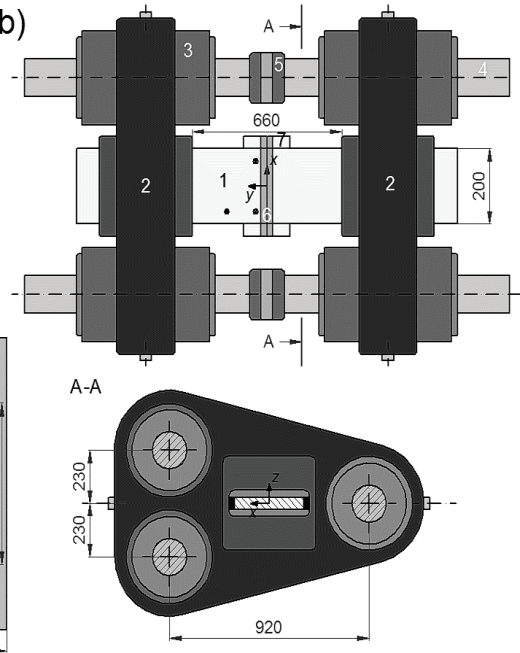

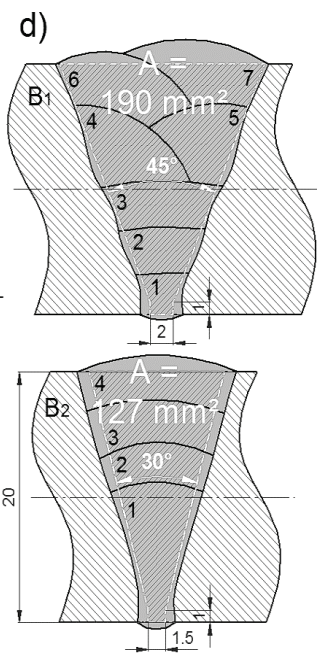

The self-restraint in weld tests no. 5 and 6 was achieved by a $200 \mathrm{~mm}$ long slot in squared plate; see Fig. 2c and 3a. For a quantification of different restraint conditions, the restraint intensity in weld transverse direction $R_{\mathrm{Fy}}$ was introduced by Satoh [12]. It is the components stiffness towards the weld seam related to the seam length. For simple butt joints it can be estimated according to [12]. The values, given in Tab. 2, were experimentally and analytically determined for each setup. They are in good agreement with typical values for mobile crane components [4].
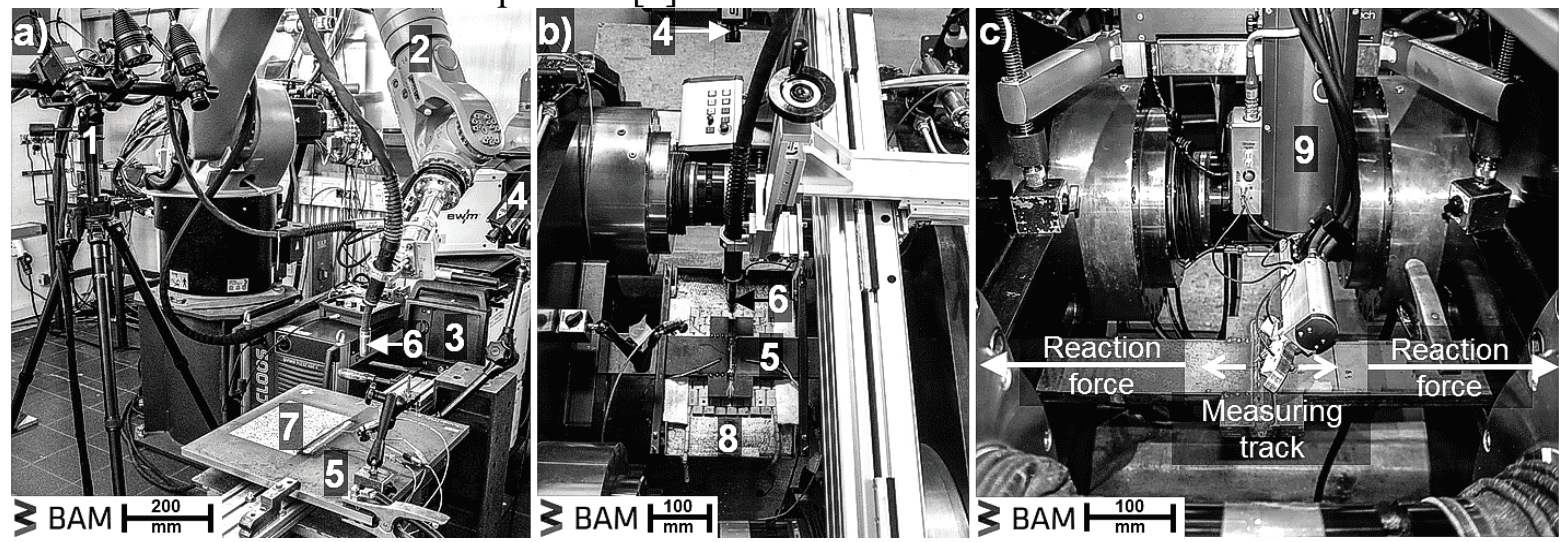

Fig. 3. Test setup: a) self-restrained weld test, b) 2-MN-testing facility, c) X-ray diffraction under restraint

(1 - DIC-system, 2 - welding robot, 3 - welding machine, 4 - two colour pyrometer, 5 - specimen with attached thermocouples, 6-GMAW-torch, 7-analysed area (DIC), 8-heating mat, 9-X-ray diffractometer).

Measurements. Type- $\mathrm{K}$ thermocouples were attached $10 \mathrm{~mm}$ adjacent to the weld to monitor the working temperature. The $\Delta t_{8 / 5}$-cooling times were determined at the weld surface using a two colour pyrometer (measuring range: $350{ }^{\circ} \mathrm{C}$ to $1300{ }^{\circ} \mathrm{C}$ ). At the testing facility, reaction forces were measured using load cells at each piston rod of the 3d-hydraulic cylinder system; see Fig. $2 \mathrm{~b}$ and $3 \mathrm{~b}$. In the slot welds, strain fields near the weld seam were measured using a DIC-system while welding and cooling; see Fig. $3 \mathrm{a}$. In the welds, local transverse residual stresses were determined via X-ray diffraction using the $\sin ^{2} \psi$ method on the top surface after cooling to ambient temperature.

\section{Results}

Global Reaction Stresses. Fig. 4a shows the reaction force $F_{\mathrm{y}}(t)$, temperature $T(t)$ and bending moment $M_{\mathrm{x}}(t)$ for test no. 3 in the 2-MN-testing facility, $\mathrm{cp}$. Table 4. Preheating of the tack welded specimen initiates compressive forces. Hence, at the beginning of the root weld, the reaction force is $F_{\mathrm{y}}=-40 \mathrm{kN}$. The bending moment remains more or less zero. While root welding, the already solidified inserted weld metal generates transversal shrinking forces and a rising of the bending moment. Both increase further to a 
first maximum of $F_{\mathrm{y}}=110 \mathrm{kN}$ and $M_{\mathrm{x}}=0.8 \mathrm{kNm}$ during cooling to $T_{\mathrm{i}}=100{ }^{\circ} \mathrm{C}$. A reduction of force and moment is obvious while welding of the second layer due to a local heat input combined with stress relief. Subsequent cooling to $T_{\mathrm{i}}$ leads to a new continuous increasing of the reaction force and bending moment, the next weld run to a force and moment reduction. This evolution of the forces and moments was detected for every weld sequence. The amplitude of the reaction force increases with every weld run as a result of the welding heat input. The amplitude of the bending moment decreases and the mean level increases slightly with each weld run due to the increasing height of the weld. However, cooling of weld run four shows an increased moment build-up with a maximum of over $M_{\mathrm{x}}=1 \mathrm{kNm}$. This is caused by the welding of the first layer above the neutral axis of the specimen in combination with an asymmetric insertion. Weld run five almost relieves this high bending moment. Subsequent cooling to ambient temperature after completion of the weld leads to a bending moment build-up of $M_{\mathrm{x}}=0.95 \mathrm{kNm}$ and to a maximum reaction force of $F_{\mathrm{y} \text {,end }}=404 \mathrm{kN}$. In Fig. $4 \mathrm{~b}$, the bending moments of the weld tests no. 3 and 4 are shown. Exceeding the neutral axis while root welding, a more symmetrical insertion of the weld metal and the reduced weld seam volume lead to reduced bending moments for the modified weld [13]. During welding, reduced amplitudes of the bending moment and after cooling to ambient temperature only $M_{\mathrm{x}}=0.1 \mathrm{kNm}$ occur. Fig. $4 \mathrm{c}$ presents a comparison of the reaction stress build-up $\sigma_{\mathrm{y}}(t)$ of both welding processes of test no. 3 and 4. $\sigma_{\mathrm{y}}(t)$ was determined using $F_{\mathrm{y}}(t)$ and the actual load bearing layer height $H_{\text {layer }}(t)$. As the two graphs exhibit the same tendency, a reduction of total welding time by $40 \%$ using the modified welding process is obvious. Further quantitative differences reveal in a decreased stress level and $10 \%$ lower end reaction stresses $\sigma_{y, \text { end }}$ after cooling to ambient temperature in the modified weld. This is caused by a reduced amount of necessary weld runs and the lower overall heat input due to the decreased weld seam volume.
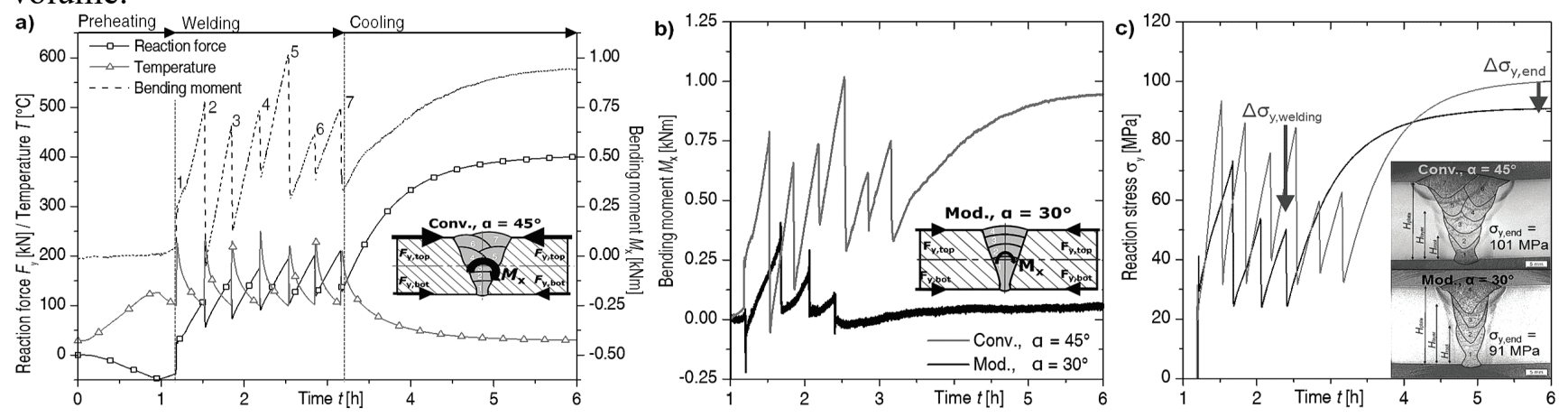

Fig. 4. a) Reaction force $F_{y}(t)$, temperature $T(t)$ and bending moment $M_{x}(t)$ for weld test no. 3; comparison of bending moments (b) and reaction stresses (c) for two different weld parameters at the 2-MN-testing facility.
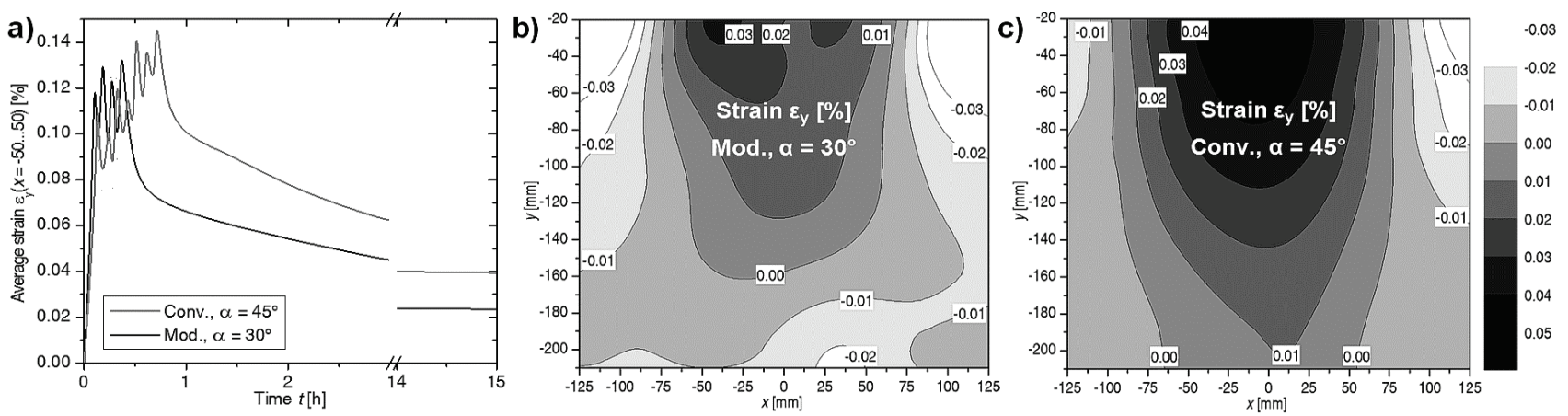

Fig. 5. Strains at the measured area of self-restrained specimens (test no. 5 and 6 ): a) average strains $\varepsilon_{y, \text { avg }}(t)$ $10 \mathrm{~mm}$ adjacent to the weld edge while preheating, welding and cooling for the different weld processes; Strain fields $\varepsilon_{y}(x, y)$ after cooling to ambient temperature for the modified (b) and the conventional weld (c).

Global strain fields. Fig. 5a shows the $\varepsilon_{\mathrm{y} \text {,avg }}(t)$-graphs measured with the DIC-system $10 \mathrm{~mm}$ adjacent to the weld edge of both weld processes at the slot welds. A decreased strain build-up while welding is revealed for the modified weld. As the graphs are qualitatively equal, the three additionally needed weld runs cause an increased expansion of about $\Delta \varepsilon_{\mathrm{y}}=0.02 \%$ at the top of the specimen towards the weld seam, 
which cannot be compensated during temperature equalization. Hence, the global strain field $\varepsilon_{\mathrm{y}}(x, y)$ after subsequent cooling to ambient temperature of the modified weld (Fig. 5b) shows significantly reduced values compared to the conventional weld (Fig. 5c).

Local Residual Stresses. Fig. $6 \mathrm{a}$ and $\mathrm{b}$ show transversal residual stress distributions measured at three different restraint conditions across the weld $(x=0 \mathrm{~mm})$. The graphs exhibit typical residual stress distributions for steels with an undergoing phase transformation and a broader stress profile for the conventional welds [8]. At the weld metal of the modified welds, higher tensile residual stresses of the amount of $60 \%$ of $R_{\mathrm{p} 0.2}$ of the weld metal are obvious, which are due to a deeper weld penetration and almost independent of the restraint condition. However, the maximum tensile residual stresses of the conventional welds $\left(\Delta \sigma_{\mathrm{y}, \mathrm{WM}}\right)$ rises with increasing restraint intensity up to $70 \%$ of $R_{\mathrm{p} 0.2}$. In the area remote to the weld, residual stresses of the restrained welds are increased due to reaction stresses $\left(\Delta \sigma_{\mathrm{y}, \mathrm{BM}}\right)$, which is also pronounced for the conventional welds; see also Fig. 4. Note that, the base material surface was blast cleaned and reveals residual stresses of about $-160 \mathrm{MPa}$. Since almost no bending moments occur in the modified welds, the bending stresses at the HAZ are similar.
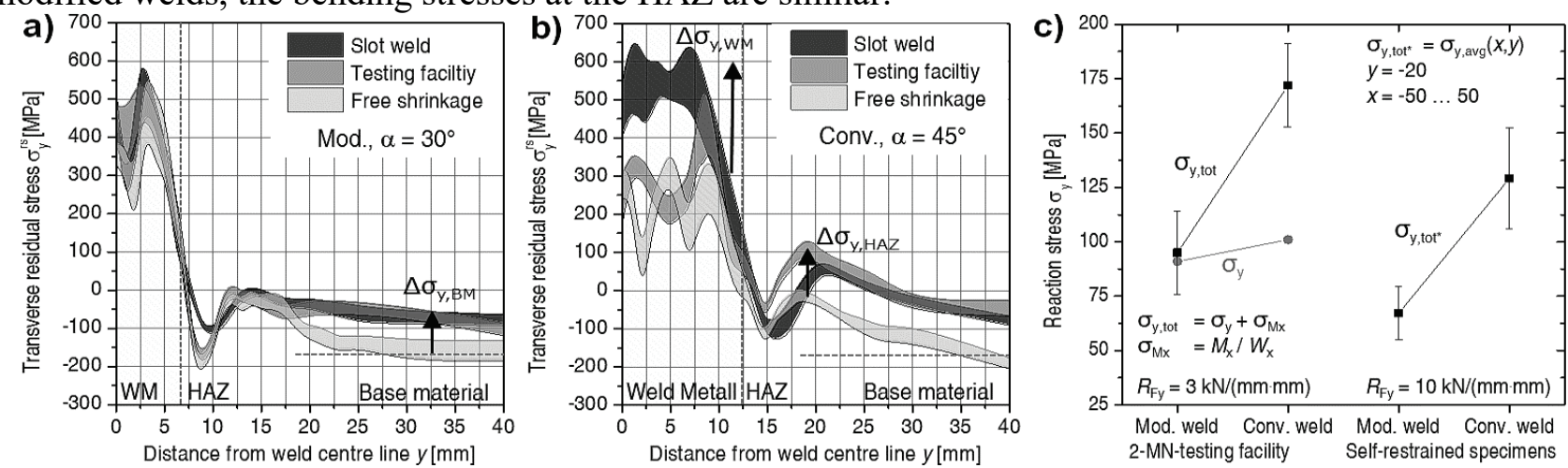

Fig. 6. Transverse residual stress distributions $\sigma^{r s}{ }_{y}(y)$ at different restraint conditions for modified (a) and conventional welds $(b)$; c) reaction stress $v$ s. welding process for restrained weld tests (calculation: $\sigma_{y, t o t}-$ reaction forces measured at 2-MN-testing facility, $\sigma_{y, t o t^{*}}$-strain field measured with DIC-system)

The conventional welds show a stress increase in the HAZ due to restrained shrinkage and angular distortion $\left(\Delta \sigma_{\mathrm{y}, \mathrm{HAZ}}\right)$. Therein, higher tensile residual stresses exhibit at the 2-MN-testing facility weld, despite a higher restraint intensity $R_{\mathrm{Fy}}$ of the slot weld. The specimens welded and measured in the testing facility reveal also higher total reaction stresses at the top of the welds, calculated by a superposition of global normal stresses $\sigma_{\mathrm{y}}$ and bending stresses $\sigma_{\mathrm{Mx}}$; see Fig. 6c. The obvious bending stress increase is a result of the high bending restraint $R_{\mathrm{Mx}}$ of the 2-MN-testing facility [14]. It is approx. 20 times as high as in the slot welds due to the comparatively long levers to the two left-hand piston rods; see Fig. $2 \mathrm{~b}$.

\section{Summary}

The present work shows the effect of the seam configuration due to a modified welding process on welding loads and stresses in butt-joints of high-strength steel components. $20 \mathrm{~mm}$ thick plates were multilayerGMA-welded under different defined restraint conditions. The groove angle of the joints was varied between $30^{\circ}$ and $45^{\circ}$ with adapted welding parameters. Occurring reaction stresses, moments and strain fields close to the seam of the restrained welds were observed in-situ while welding and cooling. Local transverse residual stresses were analysed by means of X-ray diffraction at all welds. From this work, the following conclusions can be drawn:

- While welding, decreased reaction stress amplitudes and a $10 \%$ lower end reaction stress were found for the modified weld with a reduced weld seam volume.

- In highly self-restrained specimens, the smaller groove angle leads to decreased strains adjacent to the weld by approx. $70 \%$.

- A high effect was found for the bending moment in specimens welded under high bending restraints due to the 2-MN-testing facility. The additional consideration of resulting bending stresses reveals over $80 \%$ higher total reaction stresses at the top of the conventional welds. 
- The local analyses of stress superposition at the weld area surface mainly reveals a higher effect of the restraint condition on the local residual stresses in the conventional welds, especially elevated tensile residual stresses in the critical HAZ due to increased bending stresses.

- Based on recent studies [4,6,7] this work involves a multi-axial analysis of welding stresses regarding local restraint stresses, global normal reaction stresses and bending stresses as a consequence of a lateral and angular restraint. All measurement methods are in good agreement.

- The present study accomplishes a first quantification of the beneficial effects of reduced groove angles due to modified processes for component related welds of high-strength steel S960QL.

\section{Acknowledgements}

The studies were funded by the AiF-project IGF-Nr. 17978 N / FOSTA P1011. Sincere thanks are given for this support and to the representing companies actively involved in the project board.

\section{References}

[1] H.-P. Guenther, ed., Use and Application of High-Performance Steels for Steel Structures, IABSE IVBH, Zürich, 2005.

[2] R. Rauch, S. Kapl, et al., High Strength Low Alloy Steel Weldments with Accommodated Qualities to the Base Metal, BHM Berg- und Hüttenm. Monatshefte. 157 (2012) 102-107. http://dx.doi.org/10.1007/s00501-012-0060-5

[3] J. Lu, Prestress Engineering of Structural Material: A Global Design Approach to the Residual Stress Problem, in: Handb. Residual Stress Deform. Steel, 2002: pp. 11-26.

[4] D. Schroepfer, A. Kromm, T. Kannengiesser, Improving Welding Stresses by Filler Metal and Heat Control Selection in Component-related Butt Joints of High-strength Steel, Weld. World. 59 (2015) 455464. http://dx.doi.org/10.1007/s40194-014-0219-7

[5] D. Schroepfer, T. Kannengiesser, Stress Build-up in HSLA Steel Welds due to Material Behaviour, J. Mater. Process. Technol. 227 (2016) 49-58. http://dx.doi.org/10.1016/j.jmatprotec.2015.08.003

[6] M. Rhode, A. Kromm, T. Kannengiesser, Residual Stresses in Multi-Layer Component Welds, in: Trends Weld. Res. Proc. 9th Int. Conf., ASM International, ISBN: 1-62708-998-8, Chicago, Illinois, USA, 2012: pp. 48-54.

[7] T. Lausch, T. Kannengiesser, M. Schmitz-Niederau, Multi-Axial Load Analysis of Thick-Walled Component Welds made of 13CrMoV9-10, J. Mater. Process. Technol. 213 (2013) 1234-1240. http://dx.doi.org/10.1016/j.jmatprotec.2013.01.008

[8] T. Nitschke-Pagel, H. Wohlfahrt, The Generation of Residual Stresses due to Joining Processes, in: V. Hauk, H. Hougardy, E. Macherauch (Eds.), Residual Stress. - Meas. Calc. Eval., DGM Informationsgesellschaft mbH, ISBN: 3-88355-169-4, 1991: pp. 121-133.

[9] J. Chen, C. Schwenk, et al., Predicting the Influence of Groove Angle on Heat Transfer and Fluid Flow for New Gas Metal Arc Welding Processes, Int. J. Heat Mass Transf. 55 (2011) 102-111.

[10] EN ISO 16834: Welding consumables - Wire electrodes, wires, rods and deposits for gas shielded arc welding of high strength steels - Classification, 2012.

[11] EN 10025-6: Hot rolled products of structural steels - Pt. 6: Technical delivery conditions for flat products of high yield strength structural steels in the quenched and tempered conditions, 2011.

[12] K. Satoh, Y. Ueda, S. Matsui, M. Natsume, T. Terasaki, K. Fukuda, M. Tsuji, Japanese Studies on Structural Restraint Severity in Relation to Weld Cracking, Weld. World. 15 (1977) 155-189.

[13] K. Masubuchi, Analysis of Welded Structures: Residual Stresses, Distortion, and their Consequences, Pergamon Press, 1980.

[14] K. Satoh, S. Matsui, Effect of Intensity of Bending Restraint on Weldcracking in Multipass Weld, Trans. Japan Weld. Soc. 8 (1977) 42-49. Japan Welding Society, 1977. 